\title{
Veb-Saytların Proqram Təminatının Optimallaşdırılması Məsələləri
}

\author{
Könül Daşdəmirova \\ AMEA İnformasiya Texnologiyaları İnstitutu, Bakı, Azərbaycan \\ konul22@rambler.ru
}

\begin{abstract}
Xülasə-Məqalədə veb-saytların optimallaşdırılmasıməsələləri analiz olunmuş vo bir sıra aspektlər göstərilmişdir. Veb-saytların proqram təminatının optimallaşdırılması istiqamətləri verilmişdir. Veb-analitika vasitəsilo optimallaşdırmanın üstünlükləri göstərilmişdir. Veb-saytın optimallaşdırılması sahəsində aparılan tədqaqatların bir sıra istiqamətləri tədqiq olunmuşdur.
\end{abstract}

Açar sözlor- veb-sayt, veb-saytların optimallaşdırması, vebproqramlaşdırma, veb-saytın proqram tominatı, veb-analitika, axtarış sistemlori

\section{GIRISS}

Hazırda İnternet şəbəkəsi rahat və əlverişli məlumat mübadiləsi və ünsiyyət vasitəsi olmaqla yanaşı, həm də böyük informasiya mənbəyidir. İnformasiya əsasən veb-saytlar formasında istifadəçilərə təklif olunur. Veb-saytlar bir-birilə əlaqəsi olan və vahid mövzuya həsr olunmuş veb-səhifələr sistemidir [1]. Dövlət qurumları, müxtəlif idarə, təşkilat, müəssisə və şirkətlər öz xidmətləri və imkanları haqqında məlumatları yaymaq üçün veb-saytlardan istifadə edirlər. Vebsaytlar konkret məzmuna malik olan informasiya platformasi kimi və ya gəlir qazanmaq üçün yaradılır. Bir çox ticarət mərkəzləri, mağazalar tədricən şəbəkəyə inteqrasiya edir və ya onlayn nümayəndəliklər yaradırlar. Marketoloqlar ənənəvi radio və televiziyanı diqqətdən kənar qoyaraq İnternetdə reklam şəbəkələrinə üstünlük verirlər. Şəbəkədə fəaliyyət göstərən bir çox şirkətlər öz sahiblərinə milyardlarla dollar mənfəət gətirirlər [2].

Osas məqsədi mənfəət əldə etmək olan veb-saytların irəliləməsi və axtarış sistemlərində ön sırada yerləşməsi uğur qazanmaq üçün vacib amildir. Çünki axtarış sistemlərində ilk onluqda yerləşən veb-saytlara müraciət etmə ehtimalı daha çoxdur. Lakin bir çox hallarda veb-saytın dizaynına və trafikin cəlb olunmasına çox, konversiya dərəcəsinə isə daha az diqqət yetirilir. Konversiya - veb-saytda hər hansı bir fəaliyyət göstərən ziyarətçilərin (faylların yüklənməsi, alış-veriş edilməsi, qeydiyyat, abunə, veb-saytın müəyyən səhifələrini ziyarət, reklam istinadına keçid və s.) sayının sayta daxil olan ziyarətçilərin ümumi sayına nisbətidir, faizilə ölçülür. Vebsaytın dizaynı çox gözəl olsa belə, əgər ondan istifadə etmək ziyarətçilər üçün çətindirsə və ya sayt onların ehtiyaclarına cavab vermirsə onlar bir daha həmin resursa geri qayıtmırlar [3]. Veb-saytların optimallaşdırılması problemlərinin tədqiqi və həlli yollarının göstərilməsi aktual məsələlərdən hesab olunur. Geniş istifadəçi auditoriyası üçün nəzərdə tutulmuş veb-saytların optimallaşdırılması daha zəruridir. Veb-saytın optimallaşdırılması - saytın hərtərəfli yaxşılaşdırılmasına yönəlmiş tədbirlərdəndir. Optimallaşdırmanın məqsədi vebsaytın rahatlığının təmin edilməsi, yüklənmə sürətinin artırılması, yüksək keyfiyyətli kontentin təqdim edilməsi, onun axtarış sistemlərinin tələblərinə uyğun olaraq tənzimlənməsi və sairədir.

\section{VEB-SAYTLARIN OPTIMALLAŞDIRILMASI ASPEKTLORININ ANALIZİ}

Veb-saytların kontenti mətn, şəkillər, istinadlar, cədvəllər, multimedia fayllarından (audio, video, animasiya, flash və s.), strukturu müəyyən standartlara malik olan teqlərdən, dizaynı isə qrafik təsvirlər, şriftlər və rənglərdən ibarətdir. Veb-saytın kontenti auditoriya üçün faydalı, dizaynı aydın olmalı, axtarış sistemlərində indeksləşməsi üçün teqlərdən yalnış və ya süni istifadə edilməməlidir.Bunları nəzərə alaraq veb-saytların strukturu, kontenti, dizaynı və naviqasiyasında problemlərin aşkarlanması məqsədilə auditaparılmalıdır. Həmçinin vebresursun funksionallığı, ziyarətçilərin sayının artılması, konversiyasına neqativ təsirlorin aradan qaldırılması məqsədilə saytın optimallaşdırılması zəruridir. Elektron-ticarət sahəsinə aid veb-saytların optimallaşdırılması vaxta və pula qənaət edərək biznesin inkişaf etdirilməsinə xidmət edir. Vebsaytın optimallaşdırılmasına daxil olan əsas aspektlər aşağıdakılardır [4]:

- Axtarış sistemləri üçün optimallaşdırma;

- İstifadəçilər üçün optimallaşdırma.

Axtarış sistemlari üçün optimallaşdırma (search engine optimization, SEO) veb-saytın istifadəçilərin sorğuları əsasında axtarış sistemlərində mövqeyinin yüksəldilməsi üçün daxili və xarici optimallaşdırılmaya yönəlmiş tədbirlərdəndir [5]. Axtarış sistemlərində veb-sayt nə qədər yüksək mövqeyə malik olarsa, o qədər cox ziyarətçi cəlb edər $[5,6]$. Sorğuların optimallaşdırılmasının səmərəliliyini təhlil edərkən hədəf auditoriyası və veb-saytın konversiyası qiymətləndirilir, açar sözlərin optimallaşdırılması, seçilməsi və tərtibatına diqqət yetirilir.

İstifadəçilər (usability) üçün optimallaşdırma veb-saytdan istifadənin rahatlı̆̆ının yaxşılaşdırılmasına yönəlmiş tədbirlərdəndir. Belə ki, istifadəçi yalnız veb-sayta daxil olmalı deyil, həm də lazım olan məlumatı asan tapa bilməlidir. $\mathrm{Bu}$ kimi optimallaşdırma təyinatından asılı olmayaraq bütün veb-saytlar üçün aktualdır [2].

Bunlarla yanaşı veb-saytın optimallaşdırılması üzrə aşağıdakı aspektlərə də nəzər salaq: 
- Dizaynın optimallaşdırılması-veb-saytın tərtibatı gözəl, funksional və məzmunca uyğun olmalıdır. Bütün səhifələr eyni stildə tərtib olunmalı və şirkətin stilinə uyğun gəlməlidir. Dizaynın optimallaşdırılması veb-saytın bu tələblərə cavab verməsinə xidmət edir [7].

- Sosial şəbəkələrə görə optimallaşdırma (Social media optimization, SMO) - sosial mediadan (bloq, sosial şəbəkələr və s.) ziyarətçilərin cəlb olunmasına yönəlmiş tədbirlər [8].

- Qrafikanın optimallaşdırılması veb-saytın yüklənmə vaxtını azaltmaq üçün təsvirlər və şəkillərin həcminin azaldılması, artıq qrafikanın aradan qaldırılmasıdır [9].

- Veb-analitika vasitəsilə optimallaşdırılma vebanalitikanın alətləri vo intellektual sistemlərilə toplanmış informasiyanın analizinə görə həyata keçirilir [10].

- Veb-saytın mobil qurğulara görə optimallaşdırılması. Təcrübəyə görə veb-saytın hər üç ziyarətçisindən biri veb-sayta mobil telefon və ya planşetdən daxil olur. Müasir və keyfiyyətli veb-resursa hər hansı bir qurğudan (smartfon, noutbuk, planşet, İnternetə çıxışı olan TV) daxil olmaq asan olmalıdır [11].

- Veb-saytın proqram təminatının optimallaşdırılması.

\section{VEB-SAYTLARIN PROQRAM TOMINATININ OPTIMALLAŞDIRILMASININ TODQIQI}

Veb-proqramlaşdırma - İnternetdə dinamik veb-saytların işləməsini təmin edən veb-proqramların yaradılması üçün istifadə olunur. Veb-proqramlaşdırma dilləri ilk növbədə vebtexnologiyaları ilə işləmək üçün nəzərdə tutulmuş dillərdir. Veb-proqramlaşdırma dillərini iki hissəyə bölmək olar:

- Kliyent veb-proqramlaşdırma dillori istifadəçinin kompüterində quraşdırılmış brauzerdir. Brauzer tərəfindən serverə Ajax-sorğular (səhifəni yenidən yüklənmədə server sorğuların göndərilməsi) göndərir və istifadəçinin məlumatları brauzerdə saxlanılır və emal edilir. İcra olunmuş proqramın (scriptin) nəticəsi istifadəçinin brauzerindən asılıdır. Susma rejiminə görə brauzerlərdə JavaScript proqramlaşdırma dilindən istifadə edilir.

- Server veb-proqramlaşdırma dillori müş̧ərilərin sorğularını emal edir, HTML-səhifələri dinamik formalaşdırır, verilənlər bazası ilə qarşııqlı əlaqə yaradır və $\mathrm{s}$. Server proqramlaşdırma dillərinə PHP, Python, Perl, Ruby və s. daxildir $[12,13]$.

Veb-saytın proqram təminatının optimallaşdııılması həm veb-proqramçı tərəfindən veb-proqramlaşdırma dilləri ilə, həm də avtomatlaşdırılmış proqram vasitələri ilə həyata keçirilə bilər.

Veb-saytın proqram tominatının optimallaşdırılması aşağıdakılardan ibarətdir:

\section{Veb-serverin optimallaşdırılması;}

Veb-server veb-saytın əsasını təşkil edir. O, müştəridən sorğuları qəbul edir, emal edir və müştəriyə geri göndərir. Sorğuların sayı artdıqca veb-serverin sürəti azalır.
Veb-serverin səmərəliliyini artırmaq üçün bir neçə metod mövcuddur. Bunlar aşağıdakılardır:

$\checkmark$ Sorğuların sıxılması;

$\checkmark$ Sorğuların sayının azaldılması;

$\checkmark \quad$ Veb-serverin parametrlərinin optimallaşdırılması.

Veb-serverə göndərilən sorğuların sıxılması, sayının azaldılması və parametrlərinin optimallaşdırılması $90 \%$ effektivliklə daha çox ziyarətçiyə xidmət etməyə kömək edir [14].

2. Veb-saytın irəliləməsinə mənfi təsir göstərən elementlərin aradan qaldırılması və ya dəyişdirilməsi (lazımsız JavaScript, Flash-elementləri və s.);

3. Veb-saytın axtarış alqoritmlərində daha yaxşı indeksləşdirilməsi üçün proqram kodunun, həmçinin, vebsaytın saytın naviqasiyasının, səhifələrin teqlərinin, kontentin stilinin optimallaşdırılması;

4. Seçilmiş axtarış sorğusunun əsasında veb-saytın strukturunun optimallaşdırılması. Veb-saytın xəritəsi və robots.txt fayl ilə işləmək (robots.txt faylı veb-saytın əsasında yerləşən, axtarış robotları üçün təlimat yazılmış xüsusi fayldır) [15];

5. Veb-saytın müxtəlif brauzerlərdə, əməliyyat sistemlərində və ekran ölçülərində görünüşünün optimallaşdırılması [16].

Veb-saytın müxtəlif brauzerlər, əməliyyat sistemləri və ekran ölçülərində daha yaxşı görünüşü həm veb-proqramçılar, həm də müştərilər üçün ciddi problemlər yaradır. Bunun səbəbi aşağıdakılardır:

$\checkmark$ HTML kodunun qeyri-standart xüsusiyyətlərindən istifadə. Bəzi brauzerlər HTML standartına daxil olmayan xüsusiyyətləri dəstəkləməyə bilər;

$\checkmark$ Atributların xüsusiyətlərinin susma rejminə görə təyin olunması. Hər bir HTML elementi çox saylı atributlara malikdir. Bu elementlərə rəng, qonşu elementlər arasındakı məsafə, düzləndirmək və s. aiddir. Veb-proqramçı adətən daha əhəmiyyətli olan atributların xüsusiyyətlərini təyin edir. Xüsusiyyətləri dəqiqləşdirilməmiş atributları müxtəlif brauzerlər öz susma rejmlərinə görə təyin edirlər. Bu isə öz növbəsində, veb-saytın görnüşünün fərqlənməsinə gətirib çıxarır;

$\checkmark$ Bəzi brauzerlərin “xüsusiyyətləri”. Bütün proqram təminatları kimi brauzerlərdə də xətalara rast gəlmək olar. Bu səhvləri vaxtında aradan qaldırmaq mümkündür. Lakin istifadəçilər heç də həmişə brauzerin yeni versiyasını yükləmirlər. Həmçinin brauzerləri istehsal edən şirkətlər (məsələn, Microsoft) daha yaxş1 görünüş problemini brauzerlərdə əlavə tədbirlər vasitəsi ilə həll etməyi təklif edirlər. Lakin bu tədbirlər veb-saytın adi istifadəçiləri üçün əlverişli deyil. Çoxsaylı brauzerləri və onların versiyalarını nəzərə alaraq veb-proqramçılar veb-saytın bütün brauzerlərdə düzgün görünüşünü təmin edə bilməzlər.

6. Veb-saytın məhsuldarlığının (Web performance) göstəricisi olan istifadəçinin brauzerində yüklənmə və nümayiş 
olunma sürətinin optimallaşdırılması. Veb-saytın nümayiş olunma sürətini artırmaq üçün, aşağıdakı üsullar tətbiq edilə bilər:

$\checkmark$ HTML-kodun həcminin optimallaşdırılması;

$\checkmark$ Şəkillərin həcminin optimallaşdırılması;

$\checkmark$ Multimediya fayıllarının optimallaşdırılması;

$\checkmark$ JavaScript və CSS-in optimallaşdırılmasi;

$\checkmark$ JavaScript vasitəsilə veb-saytın fayllarının həcminin və icra sürəti optimallaşdırılması [17].

\section{VEB-SAYTLARIN OPTIMALLAŞDIRILMASI SAHӘSINDӘ APARILAN TəDQIQQATLARIN İSTIQAMӘTLӘRI}

Veb-saytların optimallaşdırılması sahəsində bir sıra istiqamətlər üzrə tədqiqatlar aparılır:

1. Veb-saytların optimallaşdırılması sahəsində aparılan tədqiqatların əsas istiqamətlərindən biri veb-analitik məlumatlar əsasında veb-saytların optimallaşdırılmasıdır. Bir çox şirkətlər bu məlumatlara üstünlük verirlər. Çünki, vebsaytların inkişafinda prioritet sahələri müəyyən etmək üçün veb-analitik məlumatlar zəruridir. Bu məlumatlara "kliklər" axını, ziyarətçilərin sayı, coğrafiyası və s. aiddir. Məsələn, əgər sayt satı̧̧ alətidirsə, veb-analitikanı tətbiq etməklə düzgün biznes istiqaməti seçmək mümkündür [10].

2. İnternet şəbəkəsində biznes mühitinin yaradılması və inkişaf etdirilməsi istiqaməti üzrə veb-saytların optimallaşdırılması məsələləri tədqiq edilir. Kommersiya saytlarının problemi istifadəçilərin çox olmasına baxmayaraq, alıcıların az olmasıdır. Veb-sayt istifadəçini qane etmirsə şirkət yalnız onu deyil, onun tanışlarını da itirir və şirkətə etimad olunmur. Gəlirin artırılması üçün istifadəçilər cəlb olunmalı, müştəriyə çevrilməsi və saytda saxlanılmalıdır.

3. Veb-saytın fəaliyyətinin effektiv faktorlarından biri də sayta naviqasiyanın asan olmasıdır. Bu istiqamət üzrə bir çox alqoritmlər işlənib hazırlanmışdır.

Veb-saytların optimallaşdırılması sahəsində aparılan tədqiqatlar istifadəçilər üçün daha çəlbedici, veb-analitiklər üçün isə daha səmərəli veb-saytların yaradılmasına kömək edir.

\section{NӘTIC๐}

İnternet səbəkəsində sürətlə artmaqda olan veb-saytların optimallaşdırılması, veb-resursların funksionallığı, ziyarətçilərin sayını artırmağa, konversiya dərəcəsini yüksəltməyə və informasiya və biliklər cəmiyyətinin formalaşmasına xidmət edir.Veb-analitik məlumatlar əsasında optimallaşdırılma məsələləri veb-saytların inkişafında prioritet sahələri müəyyən etməyə kömək edir ki, bu da vətəndaşların maraqlarının öyrənilməsi, cəmiyyətin nəbzinin müəyyən olunması üçün əhəmiyyətlidir.

\section{ӘDӘВIYYAT}

[1] A.İ.Qurbanov, R.A.Abdullayeva,"Fərdi kompüterlərinproqram təminatı", II cild-Bakı, 2006, $177 \mathrm{~s}$.

[2] https://progstudy.ru/index.php/sm/article/veb-programmirovanie-uroki$\mathrm{html}$

[3] R.Page, Website Optimization: An Hour a Day,Sybex, 2012, pp. 360.

[4] http://xn--h1aieep.xn--p1ai/optimizaciya-sajta-dlya-chego-i-dlya-kogo/

[5] Б.В.Дмитриевич. «Интернет. Поиск информации. Продвижение сайтов», СПб.: БХВ-Петербург, 2000, 288 с.

[6] K.Haşımova, "İnternet mühitdə reklam xarakterli saytların optimallaşdırılması məsələləri”, İnformasiya təhlükəsizliyinin multidissiplinarproblemləri üzrə II respublika elmi-praktiki konfransı, 2015, səh..264-267.

[7] http://supporta.ru/ru/service/dopolnitelnye-uslugi/optimizatsiya-dizajnasajta/

[8] К.Максимюк, Новый Интернет для бизнеса. М.: Эксмо, 2011, 224 с.

[9] http://www.antula.ru/faq-optimization.htm

[10] B.Weischedel, E.K.R.E. Huizingh, Website Optimization with Web Metrics: A Case Study / Proceedings of the 8th International Conference on Electronic Commerce, New Brunswick, Canada, 2006, pp. 436-470

[11] http://for-joomla.net/veb-dizajn/optimizaciya-sajta-pod-mobilnyeustrojstva.html

[12] Т.В.Зудилова, М.Л.Буркова. «Web-программирование HТML», СПб: НИУ ИТМО, 2012, 70c.

[13] https://progstudy.ru/index.php/sm/article/veb-programmirovanie-uroki$\mathrm{html}$

[14] https://ruhighload.com/post/Оптимизация+Web+cервера

[15] http://qseo.ru/seo/technical\#

[16] http://help.megagroup.ru/otobrazhenie-sayta-v-raznyh-brauzer\#

[17] A.B. King, "Website Optimization," United States of America, 2008, p. 395 